\title{
Intra- and interspecific differences in palatability of Arctic macroalgae from Kongsfjorden (Spitsbergen) for two benthic sympatric invertebrates
}

\author{
Hendrik Wessels ${ }^{\mathrm{a}, *}$, Wilhelm Hagen ${ }^{\mathrm{a}}$, Markus Molis ${ }^{\mathrm{b}}$, Christian Wiencke ${ }^{\mathrm{b}}$, Ulf Karsten ${ }^{\mathrm{c}}$ \\ a University of Bremen, Marine Zoology, Leobener Straße, D-228357 Bremen, Germany \\ ${ }^{\mathrm{b}}$ Foundation Alfred Wegener Institute for Polar and Marine Research, Am Handelshafen 12, D-27570 Bremerhaven, Germany \\ ${ }^{\mathrm{c}}$ University of Rostock, Department of Biological Sciences, Applied Ecology, Albert-Einstein-Strasse 3, D-18051 Rostock, Germany
}

Received 5 January 2005; received in revised form 1 August 2005; accepted 8 August 2005

\begin{abstract}
Information on herbivore-macroalgae interactions is extremely scarce for Arctic habitats. In this study, the potential of 19 macroalgae as food source for herbivores was investigated for the first time in Arctic waters (Kongsfjorden, Spitsbergen) with emphasis on algal defense against grazing. Only two of the 19 tested macroalgae-associated invertebrates consumed macroalgae in measurable amounts, the locally abundant green sea urchin Strongylocentrotus droebachiensis (OF Müller) and the amphipod Gammarellus homari (JC Fabricius). In the inner basin of the fjord, the dense macroalgal stock represents a potential food source. However, in this area, herbivory plays only a minor role. In contrast, in the outer basin of Kongsfjorden S. droebachiensis exerts a strong top-down control on macroalgal assemblages.

Laboratory feeding assays in the with the two herbivores showed grazer-specific feeding preferences. The amphipod G. homari exhibits a preference for delicate red algal species like Devaleraea ramentacea, whereas the sea urchin $S$. droebachiensis significantly preferred more leathery seaweeds like Laminaria and Alaria. The red alga Palmaria palmata is a very attractive food for both herbivores, while the brown alga Desmarestia viridis and the red alga Ptilota gunneri are among the least preferred algae. To distinguish between physical and tissue-specific plant properties, which have a deterring or stimulating effect on the grazing behaviour, both grazers were offered intact algal tissue and artificial food in separate feeding assays. While physical and tissue-specific plant properties-especially in the Laminariales-deterred G. homari, these properties did not deter S. droebachiensis.

This study provides insights into herbivore consumption in the benthic food web of Kongsfjorden. As a general potential topdown factor controlling primary production, herbivory needs to be quantified further in Kongsfjorden to develop adequate carbon flow models for this important reference site for the study of climate change on high latitude marine ecosystems.
\end{abstract}

(C) 2005 Elsevier B.V. All rights reserved.

Keywords: Arctic; Defense; Feeding experiments; Herbivory; Kongsfjorden; Macroalgae; Plant-herbivore interactions; Spitsbergen

\footnotetext{
* Corresponding author. Fax: +49 4212182285.

E-mail address: wessels@uni-bremen.de (H. Wessels).
}

\section{Introduction}

Macroalgae play an important ecological role in shallow water coastal ecosystems (Klöser et al., 1994; Gómez et al., 1997). Although they cover only $0.1 \%$ of the world's ocean bottom area, seaweeds account for a 
disproportionally high share of global primary productivity of about 5\% (Smith, 1981). A high proportion of macroalgal communities are kelp forests, which form extensive three-dimensional habitats, thereby providing the habitat for many other species of algae, substrate for epibionts, and hunting ground, refuge, and nursery area for mobile organisms, e.g. fish.

The mobile fauna of these hard bottom communities has received little attention, and hence the trophic role of these animals from temperate regions (Hawkins and Hartnoll, 1983; Hawkins et al., 1992; Hay, 1996; Van Alstyne et al., 2001) is poorly investigated. These fauna are even less studied in polar regions. Studies from Antarctica indicate a high importance of macroalgalherbivore relationships for structuring hard bottom communities (Amsler et al., 1998; Iken, 1996; Iken et al., 1997). Nevertheless, in Antarctica the majority of macroalgal biomass appears to enter the detrital food chain (Fischer and Wiencke, 1992), although Iken (1996) showed that under laboratory conditions these plants can constitute a high proportion of the gut contents of herbivores such as fish. In sharp contrast, macroalgae-herbivore interactions in hard bottom communities from Arctic waters remain almost unstudied (but see Dunton and Schell, 1987; Sivertsen, 1997).

Marine herbivores in temperate waters can have dramatic effects on biomass, abundance, and distribution of macroalgae. For example, grazing by sea urchins, may turn kelp forests into barren grounds (Lawrence, 1975; Mann, 1982; Hagen, 1983). Hawkins et al. (1992) demonstrated that grazing by limpets was the major determinant of algal community composition. These topdown mechanisms result from high grazing pressure and hence affected algae have to tolerate herbivory or defend themselves (Lubchenco and Gaines, 1981; Duffy and Hay, 1990; John et al., 1992). To tolerate grazing, algal growth must compensate grazer-mediated loss of biomass (Paige and Whitham, 1987; Steneck et al., 1991; Horn, 1989; Littler et al., 1995), whereas defense may involve a energetically costly production of either morphological or chemical deterrents.

Rigidity and toughness of algal tissues or calcification of cell walls as found in coralline red algae represent possible morphological anti-herbivore defense mechanisms (Steneck and Watling, 1982; Padilla, 1985; Pennings et al., 1996; Taylor et al., 2002). Especially for perennial macroalgae, a deterrent morphology which also provides structural support (Pennings et al., 1996) seems to be important for long-term survival. Additionally it has been suggested that morphological defenses should be more common than chemical defenses in macroalgae with increasing latitude (Lob- ban and Harrison, 1994) as diversity and concentration of chemical defense appears to decrease with latitude (Hay and Fenical, 1992; Bolser and Hay, 1996).

Kelp-dominated algal communities at Kongsfjorden (Spitsbergen) are characterized by high biomass (up to $21 \mathrm{~kg}$ wet mass $\mathrm{m}^{-2}$; Hop et al., 2002). The macroalgal biomass represents a potentially important contribution to the shallow water ecosystem as food source, either as fresh material or as particulate organic matter (POM). While it has been suggested that in the Northern Atlantic the fraction of macroalgal production consumed as fresh algae is small (Hawkins et al., 1992), corresponding data for the Arctic are still missing.

Although two recent reviews (Hop et al., 2002; Svendsen et al., 2002) summarize the biological and physical knowledge of Kongsfjorden and emphasize its significance as a model ecosystem for western Spitsbergen fjords, neither the importance of living macroalgae as potential food for invertebrate animals nor quantitative data on consumption have been determined in Kongsfjorden (Hop et al., 2002). Therefore, the goals of this study were to (1) increase basic knowledge about benthic communities present in Kongsfjorden by studying trophic interactions between macroalgae and herbivores for the first time, (2) evaluate the importance of living macroalgae as a potential food source for the benthic fauna and with regard to (3) defense mechanisms against herbivory. To (4) differentiate between structural and non-structural defense mechanisms, feeding assays with natural herbivores from Kongsfjorden were applied providing both, fresh and reconstituted algal food.

\section{Materials and methods}

\subsection{Study site}

All laboratory experiments were conducted at the Koldewey station whereas all in-situ experiments were conducted in Kongsfjorden (Ny Ålesund, Spitsbergen, $\left.78^{\circ} 55^{\prime} \mathrm{N}, 11^{\circ} 56^{\prime} \mathrm{E}\right)$. Geological, hydrological and physico-chemical data are provided by Svendsen et al. (2002).

The sublitoral hard-bottom zones of the Arctic Kongsfjorden are dominated by a dense macroalgal community down to $30 \mathrm{~m}$ mainly consisting of Fucus distichus in the intertidal, Laminariales (kelps) in the upper sublitoral, and low-light adapted red algal species in the lower sublitoral below $13 \mathrm{~m}$. Generally, the benthic macroalgal flora of Kongsfjorden reflects a depauperate North Atlantic flora with Laminaria solidungula being the most abundant endemic species. 
A

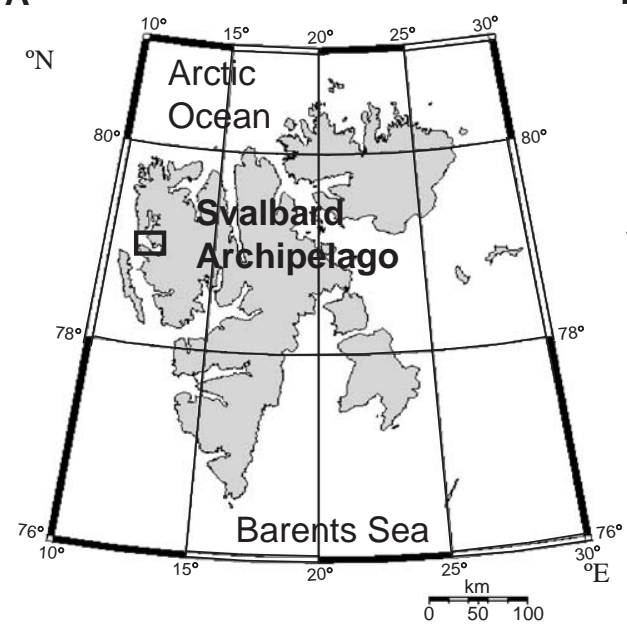

B

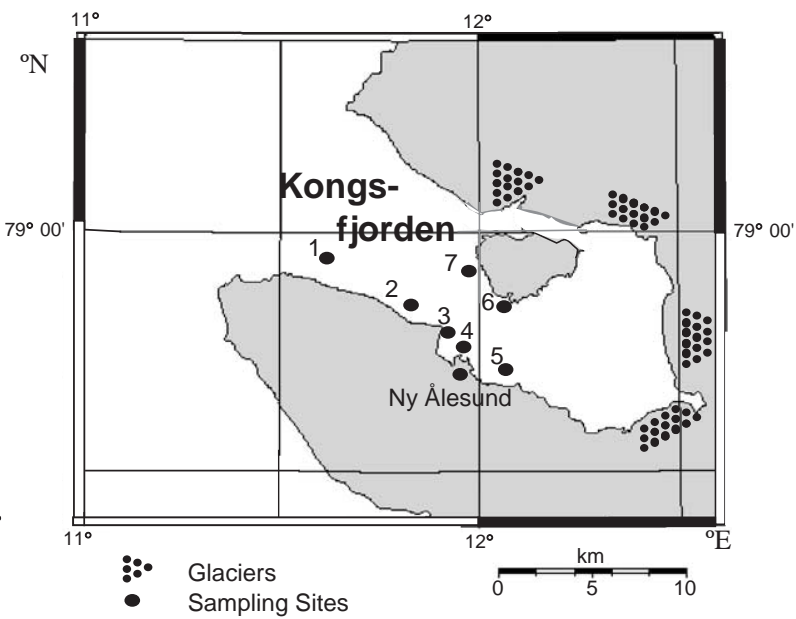

Fig. 1. (A) Geographic location of the Svalbard Archipelago and study area (insert). (B) Detail of insert and position of sampling sites (1: Kongsfjordneset; 2: Brandal; 3: Kolhamnlaguna; 4: Ny Ålesund harbour; 5: Prins Heinrichøya; 6: Ny London; 7: Hansneset) inside the area of Kongsfjorden.

\subsection{Sampling and field survey}

Using SCUBA, all organisms used for laboratory experiments were collected at depths between 1 and $22 \mathrm{~m}$ in Kongsfjorden between June and August 2002. To map the macroalgal community and associated invertebrate fauna, soft and hard bottom sites throughout the Kongsfjorden area (Fig. 1) were chosen. Each location was visually surveyed by swimming $60 \mathrm{~m}$ long transects at seven different depths $(0,5,10,15$, 20, 25, and $30 \mathrm{~m}$ ). Encountered macroalgal species were recorded to map their vertical depth range (Table 1). Twenty individuals of each of the 19 most abundant algae, which comprised $95 \%$ of total macro-

Table 1

List of investigated macroalgae, indicating sampling site (see Fig. 1 for number code), vertical distribution range, and sampling depth

\begin{tabular}{|c|c|c|c|}
\hline Species & Site & Range (m) & Depth (m) \\
\hline \multicolumn{4}{|l|}{ Chlorophyta } \\
\hline Acrosiphonia sp. & 2 & $5-18$ & 12.0 \\
\hline Chaetomorpha melagonium (F. Weber and D. Mohr) Kützing & 4 & $2-5$ & 3.5 \\
\hline \multicolumn{4}{|l|}{ Rhodophyta } \\
\hline Coccotylus truncatus (Pallas) M.J. Wynne and J.N. Heine & 6 & $18-22$ & 20.0 \\
\hline Devaleraea ramentacea (L.) Guiry & 7 & $2-5$ & 3.5 \\
\hline Odonthalia dentata (L.) Lyngbye & 6 & $18-22$ & 20.0 \\
\hline Palmaria palmata (L.) Kuntze & 2 & $12-15$ & 13.5 \\
\hline Phycodrys rubens (L.) Batters & 7 & $8-15$ & 11.5 \\
\hline Polysiphonia arctica J. Agardh & 6 & $18-22$ & 20.0 \\
\hline Ptilota gunneri P.C. Silva, Maggs and L.M. Irvine & 7 & $8-18$ & 13.0 \\
\hline \multicolumn{4}{|l|}{ Phaeophyta } \\
\hline Alaria esculenta (L.) Greville & 1 & $5-20$ & 12.5 \\
\hline Chordaria flagelliformis (O.F. Müller) C. Agardh & 7 & $1-5$ & 3.0 \\
\hline Desmarestia aculeata (L.) J.V. Lamouroux & 1 & $8-15$ & 11.5 \\
\hline Desmarestia viridis (O.F. Müller) J.V. Lamouroux & 1 & $10-12$ & 11.0 \\
\hline Dictyosiphon foeniculaceus (Hudson) Greville & 1 & $8-15$ & 11.5 \\
\hline Fucus distichus $\mathrm{L}$. & 7 & $1-5$ & 3.0 \\
\hline Halosiphon tomentosus (Lyngbye) Jaasund & 3 & $5-8$ & 6.5 \\
\hline Laminaria digitata (Hudson) J.V. Lamouroux & 5 & $5-20$ & 12.5 \\
\hline Laminaria solidungula J. Agardh & 2 & $12-20$ & 16.0 \\
\hline Laminaria saccharina (L.) J.V. Lamouroux & 5 & $5-20$ & 12.5 \\
\hline
\end{tabular}


phyte cover, were taken at the mean depth of their respective vertical distributions. To prevent osmotic or light stress, algae were kept in seawater under dark conditions during transport to the laboratory. Here algae were maintained under dim light conditions at 4 ${ }^{\circ} \mathrm{C}$ in running seawater directly pumped from the fjord until they were used in the experiments or frozen for later analysis at $-60{ }^{\circ} \mathrm{C}$.

Mobile invertebrates from the collection sites of algal samples were collected by hand or with nets pulled over individual algae, and identified in the laboratory. Preliminary feeding assays revealed the gammarid amphipod Gammarellus homari and the echinoid sea urchin Strongylocentrotus droebachiensis as the only invertebrates consuming macroalgae (Table 2).

The amphipod $G$. homari was hand-collected by divers at Hansneset (Fig. 1) between 2 and $5 \mathrm{~m}$ from the bases of its host alga Devaleraea ramentacea. Although they sometimes could be observed swimming freely or clinging to other algal species, this was the most reliable way to find individuals. Animals were kept underwater in a collection bag and transported within $1 \mathrm{~h}$ to the culture tanks in the laboratory. About 120 amphipods were maintained in a tank with running seawater at about $4{ }^{\circ} \mathrm{C}$ throughout the study period.

The sea urchin $S$. droebachiensis was collected at Kongsfjordneset (Fig. 1) at 12-15 m water depth. All

Table 2

Investigated invertebrates associated with macroalgae at Kongsfjorden and their proposed type of food $(\mathrm{h}=$ herbivorous; $\mathrm{c}=$ carnivorous; $!=$ strictly; $+=$ obligate; $\mathrm{o}=$ omnivorous) as given in the literature or observed during this study

\begin{tabular}{|c|c|c|}
\hline Group & Species & Food \\
\hline Polyplacophora & Tonicella sp. & $\mathrm{h}$ \\
\hline \multirow[t]{5}{*}{ Gastropoda } & Margarites helicinus Phipps & ! h \\
\hline & Buccinum sp. & $! \mathrm{c}$ \\
\hline & Onchidoris sp. & c \\
\hline & Facelina bostoniensis Couthouy & $\mathrm{c}$ \\
\hline & Dendronotus frondosus Ascanius & $\mathrm{c}$ \\
\hline Polychaeta & Nereis sp. & ! c \\
\hline \multirow[t]{4}{*}{ Amphipoda } & Gammarellus homari JC Fabricius & $+h^{*}$ \\
\hline & Anonyx nugax Phipps & $! \mathrm{c}$ \\
\hline & Onisimus sp. & o \\
\hline & Caprella sp. & o \\
\hline \multirow[t]{2}{*}{ Decapoda } & Sclerocrangon boreas Phipps & ! c \\
\hline & Hyas araneus Linnaeus & c \\
\hline Echinoidea & Strongylocentrotus droebachiensis OF Müller & $+\mathrm{h}^{*}$ \\
\hline \multirow[t]{5}{*}{ Asteroidea } & Pteraster pulvillus M. Sars & c \\
\hline & Henricia $\mathrm{sp}$. & $\mathrm{c}$ \\
\hline & Crossaster papposus Linnaeus & $\mathrm{c}$ \\
\hline & Asterias rubens Linnaeus & $\mathrm{c}$ \\
\hline & Hippasteria phrygiana Parelius & $\mathrm{c}$ \\
\hline
\end{tabular}

Asterisks indicate herbivores feeding on macroalgae. individuals (5-6 $\mathrm{cm}$ in diameter) were collected 2 days prior to their use in feeding assays and maintained in running seawater tanks at $4{ }^{\circ} \mathrm{C}$ under dimlight conditions.

\subsection{Laboratory no-choice feeding assays}

To determine alga-specific consumption of both grazer species, no-choice feeding assays were conducted for the 19 algal species collected.

Algae were cleaned of all macroscopic fouling organisms with a sponge, and two tissue pieces were cut from 20 individual plants of each species. Due to conspicuous morphological within-plant differences in 4 Laminariales, preference feeding assays were conducted for two tissue types (blade and stipe).

Each tissue piece was blotted, weighed, and placed in individual tanks $(2 \mathrm{~L}$ for sea urchins, $0.5 \mathrm{~L}$ for amphipods). The first tissue piece of each pair was transferred to tanks with one individual grazer, while the second piece was transferred to tanks without grazers $(n=20)$ to document autogenic changes in wet mass (Peterson and Renaud, 1989). After 24 h, grazers were removed, algae blotted and weighed, and consumption rates calculated using the formula:

Consumption $=\left[\left(T_{0} \times C_{\mathrm{f}} / C_{0}\right)-T_{\mathrm{f}}\right]$

( $T$ : wet mass treatment alga; $C$ : wet mass control alga, $C_{0}$ : before testing, $C_{\mathrm{f}}$ : after $24 \mathrm{~h} ; C_{\mathrm{f}} / C_{0}$ : mean factor of autonomous mass change for control algal pieces).

The size of all algal pieces was standardized (sea urchins: $2 \pm 0.1 \mathrm{~g}$; amphipods $0.2 \pm 0.02 \mathrm{~g}$ ) and herbivores did not consume more than $50 \%$ of each piece.

Prior to each feeding assay, sea urchins were starved for 2 days, i.e. when no more faecal pellets were produced. Individual sea urchins were used once in feeding assays.

Amphipods were starved for 1 day prior to each feeding assay, i.e. when no more faecal pellets were produced. Between the assays the amphipods were fed on D. ramentacea. Because only 120 animals could be collected in the field, individual amphipods had to be used repeatedly in feeding assays (see statistical analysis). However, no individual was used twice for the same species of algae and individual amphipods were not used in consecutive assays.

For each feeding assay, 20 amphipods were randomly chosen from the pool. All replicate plants from one algal species were tested simultaneously. Amphipods used in feeding assays were not returned to the pool before the next set of 20 animals was removed for the following experiment. 


\subsection{Preparation of artificial diets}

To determine whether a potential deterrent effect was due to physical or tissue-specific properties $30 \mathrm{~g}$ fresh mass of algal tissue from the same set of previously used individuals were shock-frozen in liquid nitrogen and homogenized using a mortar and pestle. The homogenates were added to separate pots with hot alginate $(1.8 \mathrm{~g}$ alginate (Serva) in $30 \mathrm{ml}$ heated seawater $\left.\left(60{ }^{\circ} \mathrm{C}\right)\right)$ and mixed to a homogenous solution. The solution was poured into a $100-\mathrm{ml}$ syringe and extracted into a $0.25-\mathrm{M} \mathrm{CaCl}_{2}$-solution, which led to immediate alginate gelation. The resulting gel-like strings were cut into equal-sized pieces $(0.4 \mathrm{~g}$ for the amphipods and $4 \mathrm{~g}$ for the sea urchins), which were rinsed with seawater to remove excess $\mathrm{CaCl}_{2}$. Afterwards the pellets were blotted with tissue paper in a standardized manner, weighed, offered to grazers, and reweighed at the end of the incubation time. Pilot studies revealed that alginate pellets take up water, thus increasing food mass during feeding assays by a factor of 1.12, which was used to correct consumption rates obtained from feeding assays. Preparation of artificial food diluted algal content per volume by a factor of 2. Thus grazers had to consume twice the volume of alginate-food to ingest identical amounts of algal material, compared to assays using fresh algae. To correct for this bias, consumption rates from artificial food assays were halved to keep results of fresh and artificial food assays comparable. In this way, the nutritionally inert alginate was not included in the calculation of consumption rates.

\subsection{Multiple-choice feeding assays}

To estimate sea urchin feeding preferences under natural conditions, in situ multiple-choice experiments were carried out in the field.

Weighed plant pieces from 5 individuals (2. $6 \pm 0.26 \mathrm{~g}$ [SE]) of the 23 algal diets used in the above no-choice feeding assays were randomly attached by silicone-strings to separate $14 \mathrm{~cm}^{2}$ squares on 5 perspex-plates. These plates were fixed at a depth of $12 \mathrm{~m}$ on barren ground at Kongsfjordneset (Fig. 1). Here, previous SCUBA observations had revealed that except for 5-8 individual sea urchins $\mathrm{m}^{-2}$ no other herbivoroes were present. The numbers of sea urchins on each plate were recorded daily throughout the 6-day long experiment. To account for autogenic mass changes, controls were maintained in running seawater in laboratory tanks. Sea urchins were removed daily, by transporting them $50 \mathrm{~m}$ away from the set-up. At the end of the experiment, wet mass of tissue pieces was recorded.

A similar multi-choice experiment was conducted in the laboratory, using 50 individual amphipods in an aerated $10 \mathrm{~L}$ aquarium at $4{ }^{\circ} \mathrm{C}$ and a perspex-plate $(18 \mathrm{~cm} \times 30 \mathrm{~cm})$ where 23 algal diets were fixed with rubber band on stainless steel nails sticking in the plates and exposed for $48 \mathrm{~h}$ to amphipod feeding. To determine autogenic mass changes during the assay, a second plate with equal-sized algal pieces as control was placed in another 10-L aquarium under the same conditions but without animals. Seawater was replaced every day. All algal samples were weighed before and after each test as described above and the consumed amount per alga calculated. Because the limited number of available amphipods allowed one experiment at a time, parallel replicates were not possible. Therefore the experiment was repeated 5 times, always replacing the plant pieces with new ones. Amphipods were used repeatedly.

\subsection{Statistical analysis}

To analyse differences in consumption rates of the 23 algal diets, a 1-factorial ANOVA (23 levels, fixed) was applied for no-choice experiments with the sea urchin S. droebachiensis followed by Tukey's HSD post-hoc tests. For the amphipod G. homari we had to cope with the statistical obstacle of repeatedly using animals in the no-choice experiments. We applied a 2factorial ANOVA in which we assessed (1) palatability levels of algae and (2) esurient levels of amphipods. We assumed that in the worst case only two sets of 20 amphipods were used in assays, i.e. all 20 amphipods used in assays with the first alga were reused in uneven-numbered assays up to assay 23. A second set of 20 amphipods would have been used in the second assay and all even-numbered assays up to 22 . Consequently, each of 20 amphipods from both groups may have been used in 12 and 11 assays, respectively, to test for palatability levels of 23 algae. For the analysis, amphipods were pseudo-personalised by ranking for each assay the 20 consumption values obtained from 20 amphipods in decreasing order and all values of one specific rank were assigned to one amphipod, assuming that the highest to lowest consumption rates from both amphipod groups were consistently exhibited by the most to least hungry amphipod. In this way we obtained a data set to be analysed by a 2-factorial ANOVA for main effects only, testing for algal palatability and the hunger status of amphipods. 
Prior to analysis, data were tested for normality (Kolmogorov-Smirnov) and for homoscedasticity (Levene's), but variances continued to be heterogeneous after square-root and log-transformation. Despite heterogeneous variances, data were analyzed parametrically, because our balanced design had sufficiently high numbers of treatment levels and replicates (Underwood, 1997).

To compare feeding preferences obtained from laboratory experiments with context-specific feeding preferences, consumption data from multi-choice feeding assays were tested for correlation with those from nochoice feeding assays, using Pearson's correlation.

To test for grazer-specific effects and physical structure on algal consumption rates, we applied 23 separate $2 \times 2$ ANOVAs $($ factors = grazer $[$ amphipod/sea urchin], structure [fresh plant/homogenate]). Mann-Whitney $U$ - tests were applied to test each algal species alone with only one type of grazer.

To test for tissue-specific effects on algal consumption rates for both herbivores separately, 4 two-tailed Mann-Whitney $U$-tests were applied. Data were not Bonferroni corrected (Moran, 2003). All analyses were performed with SPSS 11.0 software.

\section{Results}

The vertical distribution of the 19 most abundant macroalgal species from Kongsfjorden tested in feeding assays is presented in Table 1 . The depth range covers $1-$ $22 \mathrm{~m}$. In addition, about 100 invertebrate taxa living in association with the macrophytobenthos were identified, mostly belonging to sessile taxa. The feeding mode of

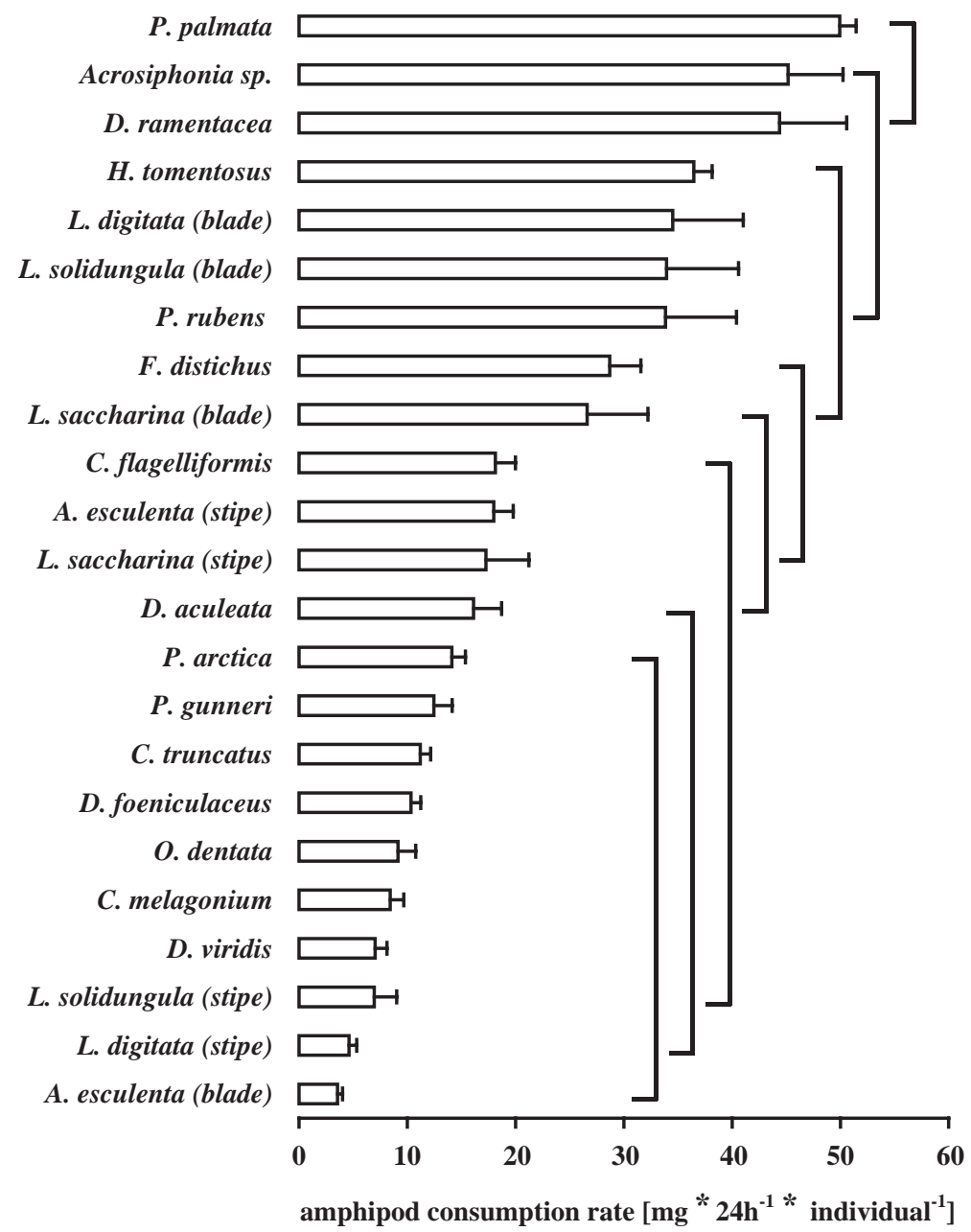

Fig. 2. Mean (+1 SE) daily consumption of individual Gammarellus homari (gammarid amphipod) for 23 macroalgal diets (19 species; 4 kelp species were subdivided into stipe and blade). Food was offered as fresh algal tissue in no-choice feeding assays under standardized laboratory conditions ( $n=20$; see Material and methods for details). Non-overlapping vertical square brackets indicate differences in consumption rates between algae at $p<0.05$ as obtained from a 2-factorial ANOVA follwed by Tukey's HSD for the first factor (consumption rates for algae). 
the 19 mobile species was studied in the field as well as under controlled conditions (Table 2). While most species did not feed on macroalgae, the amphipod $G$. homari and the locally abundant sea urchin $S$. droebachiensis (up to 35 individuals $\mathrm{m}^{-2}$; unpublished data) exhibited conspicuous herbivorous behaviour, and hence were further characterized as specialized mesograzer and generalistic macrograzer, respectively. Both invertebrates were chosen as test animals for feeding assays.

\subsection{Feeding preferences}

\subsubsection{G. homari}

Amphipods clearly consumed more of the three red algal species Palmaria palmata, D. ramentacea, Phycodrys rubens, as well as the blades of Laminaria digitata and L. solidungula, the green alga Acrosiphonia sp. and the brown alga Halosiphon tomentosus. The consumed amount per animal per day of all these algal species was above $35 \mathrm{mg}$ (Fig. 2). In contrast, the remaining algal taxa were much less consumed (Fig. 2) $\left(F_{21} ; 399=36.0\right.$, $p<0.01$ ) with $L$. saccharina (blade) and $F$. distichus consumed to an intermediate amount of $30 \mathrm{mg}$ and a group of least consumed amount below $19 \mathrm{mg}$, containing A. esculenta, the stipes of $L$. digitata and $L$. solidungula and 9 more delicate species. The difference in consumption rate between the most ( $P$. palmata) and least (A. esculenta) consumed alga was about 20 -fold.

\subsubsection{S. droebachiensis}

Relating the average body mass of sea urchins $(22.3 \pm 1.1 \mathrm{~g})$ and amphipods $(0.26 \pm 0.02 \mathrm{~g})$ to their

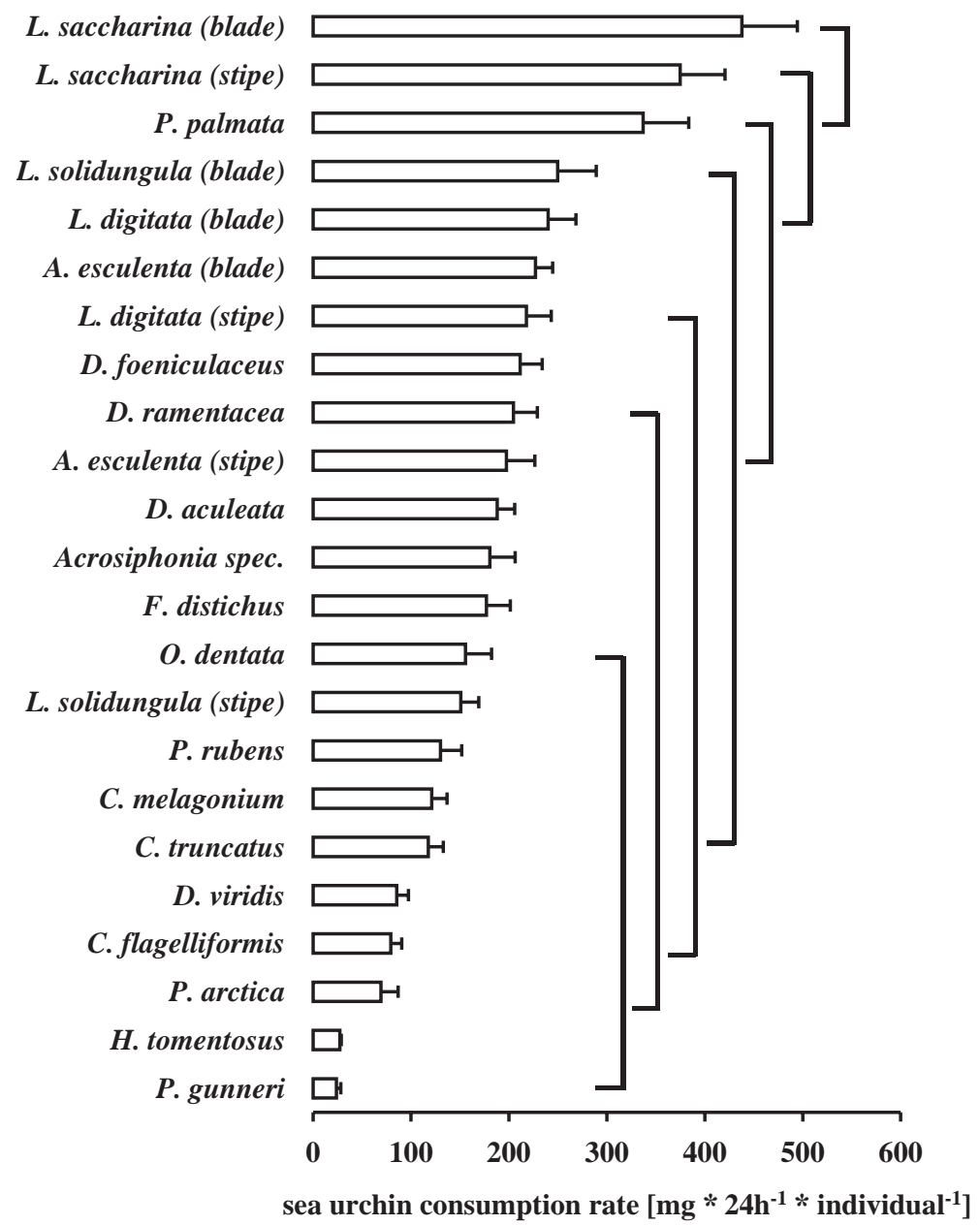

Fig. 3. Mean (+1 SE) daily consumption of individual echinoid Strongylocentrotus droebachiensis (sea urchin) for 23 macroalgal diets $(n=20)$. Food was offered as fresh algal tissue in no-choice feeding assays under standardized laboratory conditions $(n=20$; see Material and methods for details). Non-overlapping vertical square brackets indicate differences in consumption rates between algae at $p<0.05$ as obtained from a 1 -factorial ANOVA (23 levels, fixed) follwed by Tukey's HSD. 
mean daily consumption rate $(183 \pm 12 \mathrm{mg}$ versus $23 \pm 2 \mathrm{mg}$, respectively) indicate relative lower individual consumption rates in $S$. droebachiensis.

Compared to amphipods, sea urchins showed a clear preference for the blades and stipes of all three Laminaria species (except for the stipe of L. solidungula) and the red alga P. palmata, which all are grouped in the three most consumed groups. At the same time, there was a clear rejection of Ptilota gunneri and $H$. tomentosus (Fig. 3) $\left(F_{22 ; 436}=14.44 ; p<0.01\right)$. The differences in daily consumption per individual between the most preferred alga $L$. saccharina blade $(438 \pm 56.5 \mathrm{mg})$ and the least preferred alga P. gunneri $(24 \pm 4.4 \mathrm{mg}$ ) was about 20 -fold.

With the exception of P. palmata and D. ramentacea red algae are grouped in the significantly least preferred group.

\subsection{Context-specific feeding preferences}

Consumption rates determined in no-choice assays and feeding preferences determined in multi-choice assays corresponded well with one another (Table 3) for G. homari (Pearson: 0.793, $p<0.01$ ) and $S$. droebachiensis (Pearson: 0.481, $p<0.05$ ). In relation to other algal species, D. viridis is consumed in higher amounts in the multi-choice assays by both herbivores compared to the non-choice assays. Kelp stipes are consumed less in multi-choice assays by both grazers.

\subsection{Physical plant properties}

To test whether physical properties of the macroalgae affect feeding preferences of both herbivores, alginate-embedded homogenates of the tested algae were offered to both grazers. Homogenized plants were significantly preferred over intact algae in 14 species (Mann-Whitney $U$-test; $p<0.05$ ) by $G$. homari and 11 algal species by $S$. droebachiensis. Only four algae (D. viridis, $L$. solidungula stipe, $P$. palmata and $P$. arctica) showed this pattern for both grazers (Fig. 4). Of these, the relative shift to preference for homogenates was strongest with $G$. homari for $D$. viridis (8.5-fold), the blade of $A$. esculenta (9.5-fold) and the stipes of L. solidungula (9.4-fold) and L. digitata (9.4fold). Significant interactions between grazer type and food structure in 16 algal species indicate that preferences of food structure were dependent on grazer identity (Table 4). Most interesting, this was the case for all kelp stipes and the blades of $L$. digitata and L. saccharina.

Table 3

Comparison of individual consumption rates $( \pm \mathrm{SE})$ from no-choice assays $\left(c_{\text {no-choice }}: \mathrm{mg}\right.$ individual $\left.{ }^{-1} 24 \mathrm{~h}^{-1}\right)$ and total consumption rates $( \pm \mathrm{SE})$ from multi-choice assays $\left(c_{\text {multi-choice }}\right.$ mg 6 day $^{-}$super $\left.{ }^{1}\right)$ of 23 macroalgal diets for both herbivores

\begin{tabular}{|c|c|c|c|c|c|}
\hline \multicolumn{3}{|l|}{ Gammarellus homari } & \multicolumn{3}{|c|}{ Strongylocentrotus droebachiensis } \\
\hline Algal species & $c_{\text {no-choice }}$ & $c_{\text {multi-choice }}$ & Algal species & $c_{\text {no-choice }}$ & $c_{\text {multi-choice }}$ \\
\hline A. esculenta (blade) & $4 \pm 0$ & $44 \pm 11$ & P. gunneri & $24 \pm 4$ & $199 \pm 396$ \\
\hline L. digitata (stipe) & $5 \pm 1$ & $17 \pm 4$ & C. tomentosa & $27 \pm 1$ & $546 \pm 220$ \\
\hline D. viridis & $8 \pm 1$ & $214 \pm 29$ & P. urceolata & $69 \pm 17$ & $588 \pm 177$ \\
\hline L. solidungula (stipe) & $8 \pm 3$ & $33 \pm 8$ & C. flagelliformis & $79 \pm 11$ & $2639 \pm 336$ \\
\hline C. melagonium & $8 \pm 1$ & $21 \pm 4$ & D. viridis & $85 \pm 12$ & $2156 \pm 277$ \\
\hline O. dentata & $9 \pm 2$ & $43 \pm 13$ & C. truncatus & $118 \pm 15$ & $490 \pm 124$ \\
\hline D. foeniculaceus & $10 \pm 1$ & $70 \pm 17$ & C. melagonium & $121 \pm 16$ & $538 \pm 186$ \\
\hline C. truncatus & $11 \pm 1$ & $41 \pm 12$ & P. rubens & $130 \pm 22$ & $709 \pm 308$ \\
\hline P. gunneri & $12 \pm 2$ & $5 \pm 2$ & L. solidungula (blade) & $151 \pm 18$ & $3039 \pm 225$ \\
\hline P. urceolata & $14 \pm 1$ & $88 \pm 17$ & O. dentata & $156 \pm 27$ & $207 \pm 179$ \\
\hline D. aculeata & $16 \pm 3$ & $56 \pm 15$ & F. distichus & $177 \pm 25$ & $1161 \pm 299$ \\
\hline A. esculenta (stipe) & $18 \pm 2$ & $35 \pm 6$ & A. penicilliformis & $180 \pm 26$ & $1117 \pm 296$ \\
\hline C. flagelliformis & $18 \pm 2$ & $149 \pm 32$ & D. aculeata & $188 \pm 18$ & $1664 \pm 140$ \\
\hline L. saccharina (stipe) & $19 \pm 4$ & $28 \pm 5$ & A. esculenta (blade) & $197 \pm 29$ & $1869 \pm 197$ \\
\hline F. distichus & $29 \pm 3$ & $247 \pm 30$ & D. ramentacea & $205 \pm 24$ & $920 \pm 464$ \\
\hline L. saccharina (blade) & $31 \pm 6$ & $88 \pm 16$ & D. foeniculaceus & $211 \pm 22$ & $1836 \pm 479$ \\
\hline C. tomentosa & $36 \pm 2$ & $153 \pm 21$ & L. digitata (blade) & $218 \pm 25$ & $2818 \pm 308$ \\
\hline L. digitata (blade) & $38 \pm 7$ & $226 \pm 21$ & A. esculenta (stipe) & $227 \pm 18$ & $442 \pm 471$ \\
\hline P. rubens & $40 \pm 7$ & $156 \pm 36$ & L. digitata (stipe) & $240 \pm 28$ & $1603 \pm 105$ \\
\hline L. solidungula (blade) & $42 \pm 7$ & $139 \pm 29$ & L. solidungula (stipe) & $250 \pm 39$ & $951 \pm 117$ \\
\hline A. penicilliformis & $45 \pm 5$ & $297 \pm 17$ & P. palmata & $337 \pm 47$ & $2990 \pm 181$ \\
\hline D. ramentacea & $47 \pm 6$ & $294 \pm 29$ & L. saccharina (blade) & $375 \pm 46$ & $3375 \pm 239$ \\
\hline P. palmata & $50 \pm 2$ & $301 \pm 39$ & L. saccharina (stipe) & $438 \pm 57$ & $1850 \pm 142$ \\
\hline
\end{tabular}




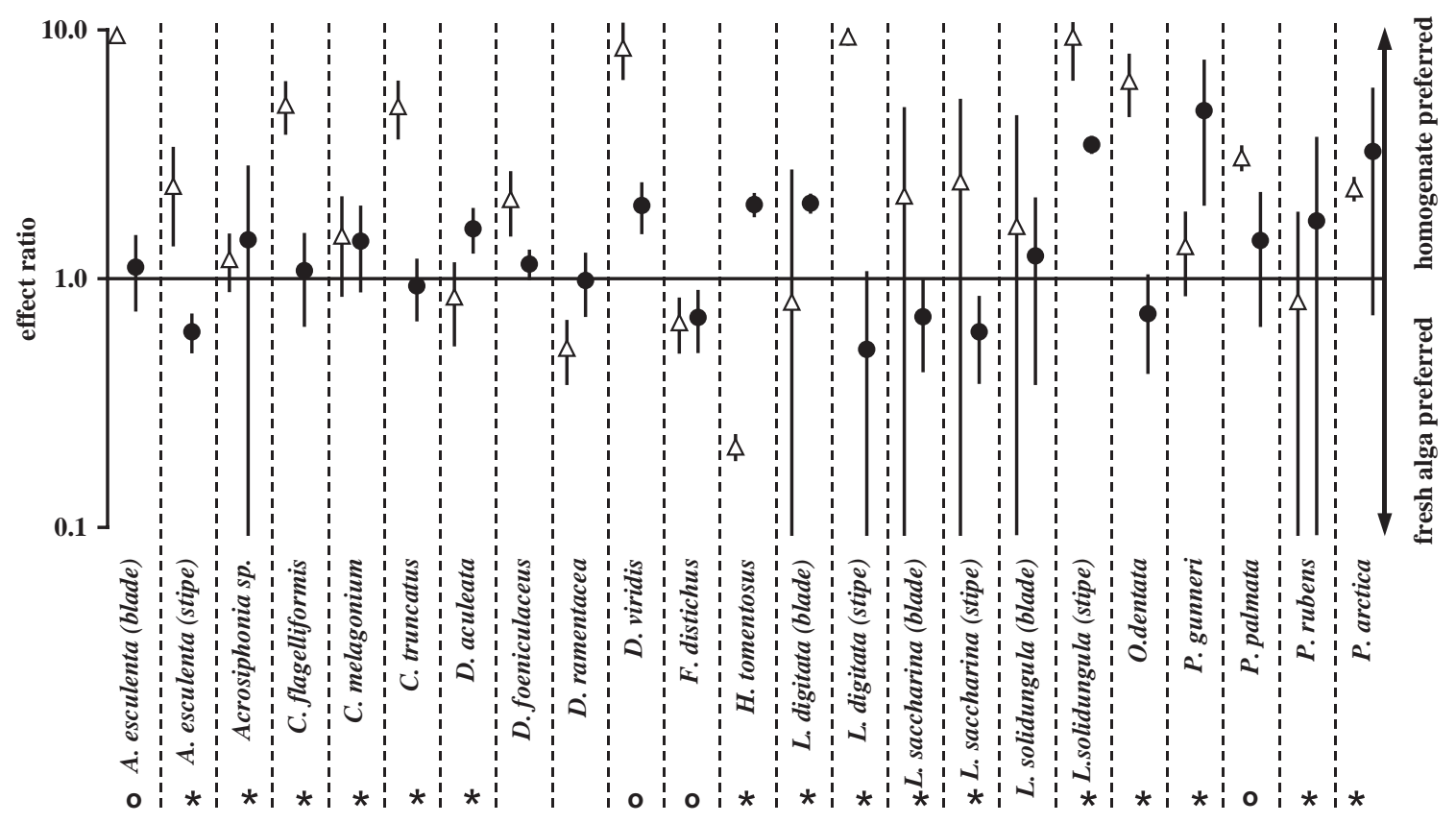

Fig. 4. Mean ( $\pm 1 \mathrm{SE})$ relative consumption rates $(C)$ between fresh and homogenated alginate-embedded algal food $\left(C_{\text {homogenated }} * C_{\text {fresh }}{ }^{-1}\right)$. (triangles $=$ amphipod; circles $=$ sea urchin). Asterisks indicate interaction $(p<0.05)$ between physical structure and grazer species as obtained from a $2 \times 2$-factorial ANOVA (factor 1: fresh/homogenated food; factor 2: amphipods/sea urchins). "o" indicate preference for the same type of food for both grazer species.

Table 4

Results of two-tailed $2 \times 2$-factor ANOVAs testing the interactive effects of algal food structure (fresh/homogenated) and type of herbivore (amphipod/sea urchin) $(p<0.05, n=16$ to 20$)$

\begin{tabular}{|c|c|c|c|c|c|c|}
\hline Algal species & $F_{\text {grazer }}$ & $P_{\text {grazer }}$ & $F_{\text {structure }}$ & $P_{\text {structure }}$ & $F_{\text {grazer*structure }}$ & $P_{\text {grazer*structure }}$ \\
\hline Acrosiphonia sp. & 141.7 & 0.000 & 9.2 & 0.003 & 5.9 & $0.018^{*}$ \\
\hline A. esculenta (blade) & 389.6 & 0.000 & 8.2 & 0.006 & 0.3 & $0.590+$ \\
\hline A. esculenta (stipe) & 75.7 & 0.000 & 3.1 & 0.082 & 11.7 & $0.001 *$ \\
\hline C. flagelliformis & 20.6 & 0.000 & 40.2 & 0.000 & 28.8 & $0.000^{*}$ \\
\hline C. melagonium & 258.1 & 0.000 & 10.4 & 0.002 & 7.5 & $0.008^{*}$ \\
\hline C. truncatus & 87.5 & 0.000 & 4.4 & 0.040 & 9.0 & $0.004 *$ \\
\hline D. aculeata & 515.1 & 0.000 & 28.8 & 0.000 & 31.3 & $0.000 *$ \\
\hline D. foeniculaceus & 287.9 & 0.000 & 2.8 & 0.096 & 0.6 & 0.442 \\
\hline D. ramentacea & 136.1 & 0.000 & 0.8 & 0.372 & 0.4 & 0.517 \\
\hline D. viridis & 118.2 & 0.000 & 127.7 & 0.000 & 0.0 & $0.901+$ \\
\hline F. distichus & 93.9 & 0.000 & 5.8 & 0.019 & 2.8 & $0.097+$ \\
\hline H. tomentosus & 103.4 & 0.000 & 0.2 & 0.675 & 229.1 & $0.000^{*}$ \\
\hline L. digitata (blade) & 326.2 & 0.000 & 42.2 & 0.000 & 47.7 & $0.000 *$ \\
\hline L. digitata (stipe) & 79.7 & 0.000 & 3.8 & 0.055 & 23.2 & $0.000^{*}$ \\
\hline L. saccharina (blade) & 97.0 & 0.000 & 2.1 & 0.155 & 6.4 & $0.014 *$ \\
\hline L. saccharina (stipe) & 101.9 & 0.000 & 4.9 & 0.030 & 10.6 & $0.002 *$ \\
\hline L. solidungula (blade) & 47.4 & 0.000 & 1.7 & 0.195 & 0.2 & 0.621 \\
\hline L. solidungula (stipe) & 182.6 & 0.000 & 100.7 & 0.000 & 48.4 & $0.000^{*}$ \\
\hline O. dentata & 52.1 & 0.000 & 0.0 & 0.876 & 10.5 & $0.002 *$ \\
\hline P. gunneri & 246.1 & 0.000 & 186.6 & 0.000 & 152.5 & $0.000^{*}$ \\
\hline P. palmata & 140.2 & 0.000 & 22.6 & 0.000 & 0.6 & $0.449+$ \\
\hline P. rubens & 84.3 & 0.000 & 7.6 & 0.007 & 10.6 & $0.002 *$ \\
\hline P. arctica & 103.7 & 0.000 & 51.2 & 0.000 & 31.9 & $0.000^{*}$ \\
\hline
\end{tabular}

“+” Indicate significant differences in preference between fresh and homogenated food for both herbivores. Asterisks indicate interaction between main factors. 


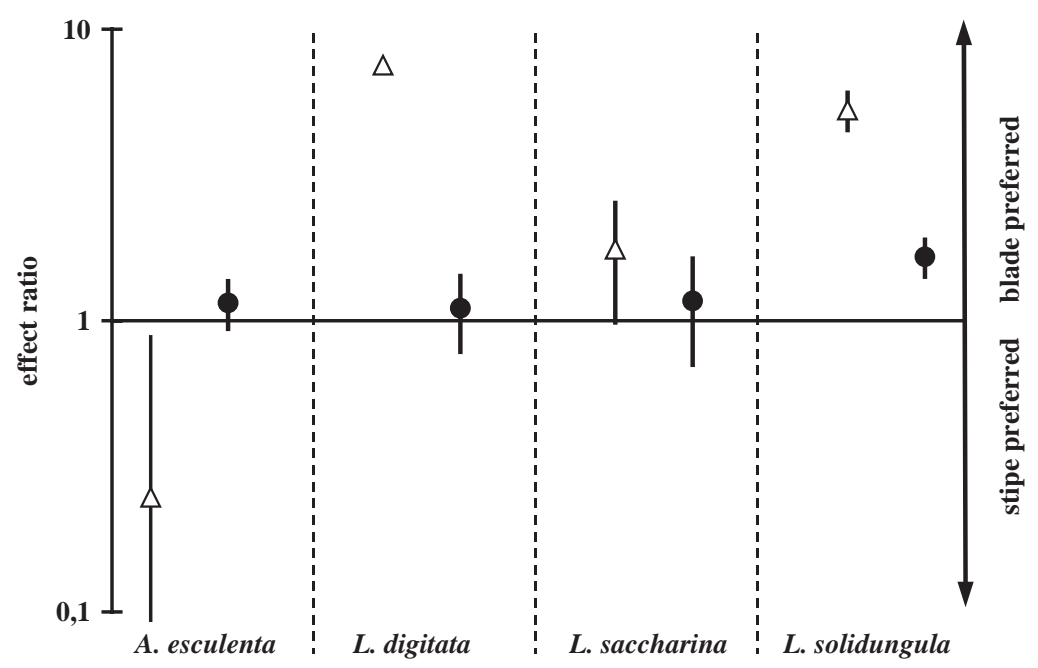

Fig. 5. Mean $( \pm 1 \mathrm{SE})$ relative consumption rates $(C)$ between blade and stipe consumption among kelp species $\left(C_{\text {blade }} * C_{\text {stipe }}{ }^{-1}\right)$. (triangles $=$ amphipod; circles $=$ sea urchin).

\subsection{Tissue-specific plant properties}

Within all kelp species where blades and stipes were tested separately, G. homari significantly (Mann-Whitney $U$-test: $p<0.05)$ preferred the blades over the stipes (L. digitata: 7.5-fold, L. saccharina, 1.8-fold, L. solidungula: 5.3 -fold) except for $A$. esculenta, where the stipe was preferred 4-fold over the blade (Fig. 5). $S$. droebachiensis did not exhibit significant preferences (Mann-Whitney $U$-test: $p>0.05$ ) for specific types of algal tissue (Fig. 5) within the kelps.

\section{Discussion}

\subsection{Herbivores in Kongsfjorden}

The present study evaluates for the first time some ecological relevances of herbivory in an Arctic macroalgal community. Although many invertebrate species could be observed in association with macroalgae, only the amphipod G. homari was identified as mesoherbivorous animal. The macroherbivorous sea urchin $S$. droebachiensis as being an opportunistic generalist. Most of the other invertebrate taxa are carnivorous, detritivorous or omnivorous (see Table 2), and instead of feeding on macroalgae, they use these plants rather as hunting ground, habitat, nursery area and shelter (Lippert et al., 2001, personal observation).

G. homari is widely distributed at boreal-arctic latitudes on both sides of the Atlantic (Bousfield, 1956; Steele, 1972; Weslawski and Legezynska, 2002). In Kongsfjorden, G. homari exhibited a strong host specificity because in most cases it was found on the basal parts of the upper sublitoral red alga $D$. ramentacea. The ecological reason for this conspicuous interspecific relationship remains unknown, although it can be speculated that due to its filamentous morphology this algal taxon may offer a particularly suitable habitat (Lippert et al., 2001; Norderhaug, 2004) besides being one of the most preferred algal species (Fig. 2; Table 3).

In laboratory feeding experiments G. homari consumed significant amounts of D. ramentacea, P. palmata and particularly A. penicilliformis (Fig. 2). Although many other macroalgal species were consumed in at least moderate quantities in the laboratory, $G$. homari was never found feeding on kelps in the field. Therefore, under in situ conditions especially chunky taxa of leathery or foliose algae like kelps or P. palmata seem not to provide refuges (Norderhaug, 2004) due to their weak suitability as substrate for clinging to.

The echinoid sea urchin $S$. droebachiensis has been reported as having a circumpolar distribution in the sublittoral on rocky grounds (Wilson and Gorham, 1982), browsing on macroalgae (Lawrence, 1975). Although $S$. droebachiensis is able to survive on almost any type of food resource (Mottet, 1976), they are highly selective on macroalgal species in laboratory experiments (Larson et al., 1980; Himmelman, 1984, Fig. 3). If macroalgae are scarce, sea urchins will scavenge on dead animals or drifting algae (Mottet, 1976; Himmelman and Steele, 1971) or even ingest sand for diatoms, radiolarians and other protozoa (Mottet, 1976). Starving may induce cannibalistic feeding behaviour as occasionally observed in this study. At lower latitudes their main predators are lobsters, crabs, 
starfish, flat fish, sea gulls and sea otters (Mottet, 1976; Himmelman and Steele, 1971; Keats et al., 1986; Keats, 1991); these are absent in Kongsfjorden. Although echinoid spines were sometimes found in faeces of sea gulls in Kongsfjorden (personal observation), these birds do not control S. droebachiensis populations at water depths below $10 \mathrm{~m}$. Other controlling factors, like mass mortalities after overgrazing events which are frequently recognized at the coasts of eastern Canada (Scheibling and Stevenson, 1984; Miller, 1985; Scheibling and Hennigar, 1997), are also missing in Kongsfjorden because the identified pathogen, Paramoeba invadens (Jones, 1985), appears to be pathogenic only at temperatures above $8{ }^{\circ} \mathrm{C}$ (Miller, 1985). Hence, $S$. droebachiensis is highly abundant $\left(=30\right.$ individuals $\left.\mathrm{m}^{2}\right)$ on rocky bottoms in the outer basin of Kongsfjorden between 8 and $18 \mathrm{~m}$ depth. Here, except for few small patches of Alaria esculenta interspersed with two Desmarestia species, most of the macroalgal canopy (mainly kelps) has disappeared due to high consumption rates. These areas have been previously described as "barren grounds" (Lawrence, 1975; Arnold, 1976; Chapman, 1981; Mann, 1982; Hagen, 1983; Schiel, 1982; Dean et al., 1984; Harrold and Pearse, 1987; Watanabe and Harrold, 1991).

In laboratory experiments $S$. droebachiensis showed the highest consumption rates for leathery species like the blades of the kelps. Most other algal taxa were consumed in much smaller amounts. H. tomentosus and $P$. gunneri were mainly rejected. However, in the field $S$. droebachiensis not only will browse on less preferred algal taxa after diminishing of preferred taxa (Hagen, 1983), but will also survive at places where kelp forests have disappeared (Lang and Mann, 1976).

Despite dense macroalgal canopy on rocky bottoms, S. droebachiensis was never present in the inner basin of Kongsfjorden. Although experimental evidence is missing, possible explanations point to factors such as increased sedimentation, turbidity, and glacial freshwater influx interferring with sea urchin development (Himmelman, 1984). Furthermore, coralline red algae, which can support sea urchin larval metamorphosis (Pearce and Scheibling, 1990), are missing in the inner part of the basin. This might have additional negative effects on sea urchin recruitment.

The data presented provide further evidence to the widely accepted latitudinal gradient in herbivory in the northern hemisphere, i.e. decreasing grazing pressure with increasing latitudes due to a lower diversity of herbivores (Fenical, 1980; Hay, 1981; Hay and Steinberg, 1992; Bolser and Hay, 1996). In tropical and temperate regions, most mesoherbivores show nocturnal activity for better protection against visually hunting predators like fish and birds (Brawley, 1992). Polar regions exhibit $24 \mathrm{~h}$ daylight during summer, and hence diurnal and nocturnal activity patterns of mesograzers should not be present during this time. The generally low number of herbivores-at least for the period of this study-cannot be explained by predation, because predators such as the shorthorn sculpin (Myxocephalus scorpius) and the striped snailfish (Liparis liparis) were only occasionally observed in sublittoral benthic communities of Kongsfjorden, as were predating invertebrates such as the crustaceans Sclerocrangon boreas or Hyas araneus. These observations are in agreement with the data of Lippert (2004), who reported low incidence of predation on 18 abundant sessile or slow-moving invertebrates in Kongsfjorden. Therefore, it seems that the low number of herbivores in Arctic waters is more related to factors such as food quality or physical properties of macroalgae that may influence mesoherbivore diversity and population structure. It has been suggested that the relatively young evolutionary history of the Arctic Ocean (Dayton et al., 1994) contributes to a generally low biodiversity due to a relatively short period for adaptation and speciation (Gray, 2001). Another aspect could be the principal inefficiency of macroalgae as nutritional source (Hessen, 1992; Sterner and Hessen, 1994) (e.g. N-limitation). Norderhaug et al. (2003) showed that amphipods from Northern Norway only fed on kelps after the algal tissue had gone through a significant bacterial degradation, i.e. $\mathrm{N}$-enrichment.

\subsection{Algal defense against herbivory}

Feeding preferences from bioassays can vary depending on various factors such as the number of offered food choices (Lubchenco and Gaines, 1981). Already slightly deterrent effects could be sufficient to make herbivores select for the more palatable food in multi-choice assays, whereas less palatable food may still be accepted in no-choice assays (Lippert and Iken, 2003). Hence, multi-choice assays are important to gain information on the degree of palatability in a range of offered food items. In contrast, the no-choice experiments only quantify the maximum feeding rate for each provided alga, without giving information about preference under natural conditions. However, the correlation (Pearson) between both kinds of experiments was quite high in this study (G. homari: 0.793, $p<0.01, S$. droebachiensis: 0.481, $p<0.05)$. Both amphipod and sea urchin experiments gave consistent results supporting the view that palatability is of crucial importance not only for the selection of the species in multi-choice 
experiments but also for the specific consumption rate in no-choice experiments.

In general, consumption rankings for fresh algal tissue was not maintained after homogenization. Physical structure in terms of rigidity and toughness seem to act as effective deterrent factor against the consumption by the amphipod, but were much less effective against the sea urchin (Fig. 4). Although as fresh algae, differences in consumption between stipe and blade were higher, overall preferential order did not change after homogenization. This indicates that morphology is not the only reason for preferential feeding by sea urchins. The very high consumption rate of the formerly rejected Desmarestia viridis in the multi-choice assays can be explained by the fact that it was dead by the time of the experiments. D. viridis contains sulfuric acid in the vacuoles (Wirth and Rigg, 1936; Eppley and Bovell, 1958), which acts as antigrazing agent against sea urchins (Pelletreau and Muller-Parker, 2002) The acid, however, kills the algal cells if released due to mechanical damage. With the release of sulfuric acid, this species looses its chemical deterrent and is now an attractive food for grazers (Konar, 2000). This was also the case in the no-choice experiments with the artificial food (Fig. 4). A few algal species, such as P. gunneri, which were rarely consumed both as fresh and as homogenized food, may be protected by chemical defense. This has to be tested in further analyses.

Tissue-specific, within-plant differences can have effects on consumption rates by mesoherbivores which can be important for perennial species like kelps. Grazing on the blades can be compensated in the following growth period if stipes remain largely undamaged. High abundances of mobile mesoherbivores would not, therefore, be able to deforest kelp beds, despite of high grazing pressure. In contrast, sea urchin grazing is not influenced by within-plant differences in tissue structure (Fig. 5). Although Hagen (1983) reported that kelp forests show that stipes are consumed only after blades and epiphytic algae have been eaten, this pattern was not observed for A. esculenta, L. saccharina, L. digitata, and L. solidungula in this study. If natural predators or mass-mortalities of sea urchins caused by pathogens are missing, no reforestation of overgrazed kelp beds in Kongsfjorden is expected, since juvenile plants will be cleared away before they reach reproductive maturity.

\subsection{Conclusion}

In contrast to comparable Antarctic habitats, the shallow water macroalgal communities of Kongsfjor- den are poor in herbivorous animals except for local areas with high densities of $S$. droebachiensis resulting in high grazing pressure and top-down control (unpublished data). Confirming the latitudinal hypothesis, the low number of herbivores is reflected by a low incidence of strong defense mechanisms. These mainly consist of structural features which have an effect against mesoherbivores but not macroherbivores. As demonstrated in zoobenthic communities of Kongsfjorden (Lippert and Iken, 2003; Lippert, 2004), strongly deterrent chemical defenses do at least not seem to be common in macrophytobenthic communities since after homogenization most algal species were consumed by both herbivores studied.

\section{Acknowledgements}

Financial support by the Deutsche Forschungsgemeinschaft to W. Hagen (HA 1706/6-1/2) and U. Karsten (Ka 899/6-1/2) is gratefully acknowledged. We also thank the AWI diving team for support in the field. Moreover, we thank the Ny Ålesund International Arctic Environmental Research and Monitoring Facility for their support. We are grateful for statistical support by Werner Wosniok. [AU]

\section{References}

Amsler, C.D., McClintock, J.B., Baker, B.J., 1998. Chemical defense against herbivory in the Antarctic marine macroalgae Iridaea cordata and Phyllophora antarctica (Rhodophyceae). J. Phycol. 34, 53-59.

Arnold, D.C., 1976. Local denudation of the sublittoral fringe by the green sea urchin, Strongylocentrotus droebachiensis (O.F. Muller). Can. Field-Nat. 90, 186-187.

Bolser, R.C., Hay, M.E., 1996. Are tropical plants better defended? Palatability and defenses of tropical vs. temperate seaweeds. Ecology 77, 2269-2286.

Bousfield, E.L., 1956. Studies on the shore Crustacea collected in eastern Nova Scotia and Newfoundland, 1954. Bull.-Natl. Mus. Can. 142, 127-152.

Brawley, S.H., 1992. Mesoherbivores. In: John, D.M., Hawkins, S.J., Price, J.H. (Eds.), Plant-Animal Interactions in the Marine Benthos. Clarendon Press, Oxford, UK, pp. 235-263.

Chapman, A.R.O., 1981. Stability of sea urchin dominated barren grounds following destructive grazing of kelp in St. Margaret's Bay, Eastern Canada. Mar. Biol. 62, 307-311.

Dayton, P.K., Mordida, B.J., Bacon, F., 1994. Polar marine communities. Am. Zool. 34, 90-100.

Dean, T.A., Schroeter, S.C., Dixon, J.D., 1984. Effects of grazing by two species of sea urchins (Strongylocentrotus franciscanus and Lytechinus anamesus) on recruitment and survival of two species of kelp (Macrocystis pyrifera and Pterygophora californica). Mar. Biol. 1978, 301-313.

Duffy, J.E., Hay, M.E., 1990. Seaweed adaptions to herbivory. Bioscience 40 (5), 368-375. 
Dunton, K.H., Schell, D.M., 1987. Dependence of consumers on macroalgal (Laminaria solidungula) carbon in an arctic kelp community: d13C evidence. Mar. Biol. 93, 615-625.

Eppley, R.W., Bovell, C.R., 1958. Sulfuric acid in Desmarestia. Biol. Bull. 115, 101-106.

Fenical, W., 1980. Distributional and taxonomic features of toxinproducing marine algae. In: Abbott, I.A., Foster, M.S., Eklund, L.F. (Eds.), Pacific Seaweed Aquaculture. California Sea Grant College Program, Institute of Marine Resources, University of California, La Jolla, CA, USA, pp. 144-151.

Fischer, G., Wiencke, C., 1992. Stable carbon isotope composition, depth distribution and fate of macroalgae from the antarctic Peninsula region. Polar Biol. 12, 341-348.

Gómez, I., Weykam, G., Klöser, H., Wiencke, C., 1997. Photosynthetic light requirements, metabolic carbon balance and zonation of sublitoral macroalgae from King George Island (Antarctica). Mar. Ecol. Prog. Ser. 148, 281-293.

Gray, J.S., 2001. Marine diversity: the paradigms in patterns of species richness examined. Sci. Mar. 65, 41-56.

Hagen, N.T., 1983. Destructive grazing of kelp beds by sea urchins in Vestfjorden, northern Norway. Sarsia 68, 177-190.

Harrold, C., Pearse, J.S., 1987. The ecological role of echinoderms in kelp forests. In: Jangoux, M., Lawrence, J.M. (Eds.), Echinoderm Studies. AA Balkema, Rotterdam, pp. 137-233.

Hawkins, S.J., Hartnoll, R.G., 1983. Grazing of intertidal algae by marine invertebrates. Oceanogr. Mar. Biol. Ann. Rev. 21, $195-282$.

Hawkins, S.J., Hartnoll, R.G., Kain, J.M., Norton, T.A., 1992. Plant-animal interaction on hard substrata in the north-east Atlantic. In: John, D.M., Hawkins, S.J., Price, J.H. (Eds.), PlantAnimal Interactions in the Marine Benthos. Clarendon Press, Oxford, UK, pp. 1-32.

Hay, M.E., 1981. Spatial patterns of grazing intensity on a Caribbean barrier reef: herbivory and algal distribution. Aquat. Bot. 11, 97-109.

Hay, M.E., 1996. Marine chemical ecology: what's known and what's next? J. Exp. Mar. Biol. Ecol. 200 (1-2), 103-134.

Hay, M.E., Fenical, M.E., 1992. Chemical mediation of seaweedherbivore interactions. In: John, D.M., Hawkins, S.J., Price, J.H. (Eds.), Plant-Animal Interactions in the Marine Benthos. Clarendon Press, Oxford, UK, pp. 319-337.

Hay, M.E., Steinberg, P.D., 1992. The chemical ecology of plantherbivore interactions in marine versus terrestrial communities. In: Rosenthal, J.A., Berenbaum, M.R. (Eds.), Herbivores: Their Interaction with Secondary Metabolites, Evolutionary and Ecological Processes. Academic Press, San Diego, pp. 371-413.

Hessen, D.O., 1992. Nutrient element limitation of zooplankton production. Am. Nat. 140 (5), 799-814.

Himmelman, J.H., 1984. Urchin feeding and macroalgal distribution in Newfoundland, Eastern Canada. Nat. Can., Rev. Ecol. Syst. $111,337-348$.

Himmelman, J.H., Steele, D.H., 1971. Food and predators of the green sea urchin Strongylocentrotus droebachiensis in Newfoundland waters. Mar. Biol. 9, 315-322.

Hop, H., Pearson, T., Hegseth, E.N., Kovacs, K.M., Wiencke, C., Kwasniewski, S., Eiane, K., Mehlum, F., Gulliksen, B., Wlodarska-Kowalczuk, M., Lydersen, C., Weslawski, J.M., Cochrane, S., Gabrielsen, G.W., Leakey, R.J.G., Lønne, O.J., Zajaczkowski, M., Falk-Petersen, S., Kendall, M., Wängberg, S.-Å., Bischof, K., Voronkov, A.Y., Kovaltchouk, N.A., Wiktor, J., Poltermann, M., di Prisco, G., Papucci, C., Gerland, S., 2002. The marine ecosystem of Kongsfjorden, Svalbard. Polar Res. 21 (1), 167-208.
Horn, M.H., 1989. Biology of marine herbivorous fishes. Oceanogr. Mar. Biol. Ann. Rev. 27, 167-272.

Iken, K., 1996. Trophic relations between macroalgae and herbivores in Potter Cove (King George Island, Antarctica). Thesis. Reports on Polar Research, 201. 205 pp. (in German).

Iken, K., Barrera-Oro, E.R., Quartino, M.L., Casaux, R.J., Brey, T., 1997. Grazing in the Antarctic fish Notothenia coriiceps: evidence for selective feeding on macroalgae. Antarct. Sci. 9 (4), 386-391.

John, D.M., Hawkins, S.J., Price, J.H., 1992. Plant-animal interactions in the marine benthos. Systematics Association Special Volume, vol. 46. Clarendon Press, Oxford, England.

Jones, G.M., 1985. Paramoeba invadens n. sp. (Amoeba:Paramoebaidae), a pathogenic amoeba fro the sea urchin, Strongylocentrotus droebachiensis in easten Canada. J. Protozool. 34, $564-569$.

Keats, D.W., 1991. American plaice, Hippoglossoides platessoides (Fabricius), predation on green sea urchins, Strongylocentrotus droebachiensis (O.F. Muller), in Eastern Newfoundland. J. Fish Biol. 38, 67-72.

Keats, D.W., Steele, D.H., South, G.R., 1986. Ocean pout (Macrozoarces americanus) (Bloch and Schneider) (Pices:Zoarcidae) predation on green sea urchin (Strongylocentrotus droebachiensis) (O.F. Mull.) (Echinodermata:Echinoidea) in eastern Newfoundland). Can. J. Zool. 65, 1515-1521.

Klöser, H., Mercury, G., Laturnus, F., Quartino, M.L., Wiencke, C., 1994. On the competitive balance of macroalgae at Potter Cove (King George Island South Shetlands). Polar Biol. 14, 11-16.

Konar, B., 2000. Seasonal inhibitory effects of marine plants on sea urchins: structuring communities the algal way. Oecologia 125, $208-217$.

Lang, C., Mann, K.H., 1976. Changes in sea urchin populations after the destruction of kelp beds. Mar. Biol. 36, 321-326.

Larson, B.R., Vadas, R.L., Keser, M., 1980. Feeding and nutritional quality of the sea urchin, Strongylocentrotus droebachiensis. Mar. Biol. 59, 49-62.

Lawrence, J.M., 1975. On the relationship between marine plants and sea urchins. Oceanogr. Mar. Biol. Ann. Rev. 13, 213-286.

Lippert, H., 2004. Chemical ecology and palatability of marine invertebrates in the sub-Arctic Kongsfjord. Thesis. Reports on Polar Research 465.

Lippert, H., Iken, K., 2003. Biochemical composition and palatability of invertebrates in a sub-Arctic fjord. Mar. Biol. Assoc. UK 83, $1215-1219$

Lippert, H., Iken, K., Rachor, E., Wiencke, C., 2001. Macrofauna associated with Macroalgae in the Kongsfjord (Spitsbergen). Polar Biol. 24, 512-522.

Littler, M.M., Littler, D.S., Taylor, P.R., 1995. Selective herbivore increases biomass of its prey: a chiton-coralline reef-building association. Ecology 76, 1666-1681.

Lobban, C.S., Harrison, P.J., 1994. Seawed Ecology and Physiology. Cambridge University Press, New York. 366 pp.

Lubchenco, J., Gaines, S.D., 1981. A unified approach to marine plant-herbivore interactions: I. Populations and communities. Ann. Rev. Ecolog. Syst. 12, 405-437.

Mann, K.H., 1982. Kelp, Sea urchins and predators: a review of strong interactions in rocky subtidal systems of eastern Canada, 1970-1980. Neth. J. Sea Res. 16, 414-423.

Miller, R.J., 1985. Succession in sea urchin and seaweed abundance in Nova Scotia, Canada. Mar. Biol. 84, 275-286.

Moran, M.D., 2003. Arguments for rejecting the sequential Bonferroni in ecological studies. Oikos 100, 403-405. 
Mottet, M.G., 1976. The Fishery Biology of sea urchins of the family Strongylocentrodiae. Technical Report No. 20. State of Washington Department of Fisheries Shellfish Division. 66 ff.

Norderhaug, K.M., 2004. Use of red algae as hosts by kelp-associated amphipods. Mar. Biol. 144, 225-230.

Norderhaug, K.M., Fredriksen, S., Nygaard, K., 2003. Trophic importance of Laminaria hyperborea to kelp forest consumers and the importance of bacterial degradation to food quality. Mar. Ecol. Prog. Ser. 255, 135-144.

Padilla, D.K., 1985. Structural resistance of algae to herbivores. Mar. Biol. 1990, 103-109.

Paige, K.N., Whitham, T.G., 1987. Overcompensation in response to mammalian herbivory: the advantage of being eaten. Am. Nat. 129, 407-416.

Pearce, C.M., Scheibling, R.E., 1990. Induction of metamorphosis of larvae of the green sea urchin, Strongylocentrotus droebachiensis, by coralline red algae. Biol. Bull. 179, 304-311.

Pelletreau, K.N., Muller-Parker, G., 2002. Sulfuric acid in the phaeophyte alga Desmarestia munda deters feeding by the sea urchin Strongylocentrotus droebachiensis. Mar. Biol. 141, 1-9.

Pennings, S.C., Puglisi, M.P., Pitlik, T.J., Himaya, A.C., Paul, V.J., 1996. Effects of secondary metabolites and $\mathrm{CaCO}^{3}$ on feeding by surgeonfishes and parrotfishes: within-plant comparisons. Mar. Ecol. Prog. Ser. 134, 49-58.

Peterson, C.H., Renaud, P.E., 1989. Analysis of feeding preference experiments. Oecologia 80, 82-86.

Scheibling, R.E., Hennigar, A.W., 1997. Recurrent outbreaks of disease in sea urchins Strongylocentrotus droebachiensis along the Atlantic coast of Nova Scotia: evidence for a link with large-scale meteorologic and oceanographic events. Mar. Ecol. Prog. Ser. $152,155-165$.

Scheibling, R.E., Stevenson, R.L., 1984. Mass mortality of Strongylocentrotus droebachiensis (Echniodermata:Echinoidea) off Nova Scotia, Canada. Mar. Biol. 78, 153-164.

Schiel, D.R., 1982. Selective feeding by the echinoid, Evichinus chloroticus and the removal of plants from subtidal algal stands in Northern New Zealand. Oecologia 54, 379-388.

Sivertsen, K.M., 1997. Geographic and environmental factors affecting the distribution of kelp beds and barren grounds and changes in biota associated with kelp reduction at sites along the Norwegian coast. Can. J. Fish. Aquat. Sci. 54, 2872-2887.

Smith, S., 1981. Marine macrophytes as global carbon sink. Science 211, 838-840.

Steele, D.H., 1972. Some aspects of the biology of Gammarellus homari (Crustacea, Amphipoda) in the Northwestern Atlantic. J. Fish. Res. Board Can. 29 (9), 1340-1343.

Steneck, R.S., Watling, L., 1982. Feeding capabilities and limitation of herbivorous molluscs: a functional group approach. Mar. Biol. 68, 299-319.

Steneck, R.S., Hacker, S.D., Dethier, M.N., 1991. Mechanisms of competitive dominance between crustose coralline algae: an herbivore-mediated competitive reversal. Ecology 72, 938-950.

Sterner, R.W., Hessen, D.O., 1994. Algal nutrient limitation and the nutrition of aquatic herbivores. Ann. Rev. Ecolog. Syst. 25, 1-29.

Svendsen, H., Beszczynska-Møller, A., Hagen, J.O., Lefauconnier, B., Tverberg, V., Gerland, S., Ørbaek, J.B., Bischof, K., Papucci, C., Zajaczkowski, M., Azzolini, R., Bruland, O., Wiencke, C., Winther, J.G., Dallmann, W., 2002. The physical environment of Kongsfjorden - an Arctic fjord system in Svalbard. Polar Res. 21, $167-208$.

Taylor, R.B., Sotka, E.E., Hay, M.E., 2002. Tissue-specific induction of herbivore resistance. Oecologia 132, 68-76.

Underwood, A.J., 1997. Experiments in Ecology. Cambridge University Press, New York.

van Alstyne, K.L., Wolfe, G.V., Freidenburg, T.L., Neill, A., Hicken, C., 2001. Activated defense systems in marine macroalgae: evidence for an ecological role for DMSP cleavage. Mar. Ecol. Prog. Ser. 213, 53-65.

Watanabe, J.M., Harrold, C., 1991. Destructive grazing by sea urchins Strongylocentrotus ssp. In a central California kelp forest: potential roles of recruitment, depth and predation. J. Exp. Mar. Biol. Ecol. 71, 125-141.

Weslawski, J.M., Legezynska, J., 2002. Life cycles of some Arcitc amphipods. Pol. Polar Res. 23, 253-264.

Wilson, J.R., Gorham, A.H., 1982. Alaska's Underutilized Species Volume III Sea Urchin. Alaska Sea Grant College Program University of Alaska Fairbanks AlaskaSea Grant Report, pp. 82-87.

Wirth, H.E., Rigg, G.B., 1936. The acidity of the juice of Desmarestia. Am. J. Bot. 24, 68-70. 